\title{
Effect of vesicular-arbuscular mycorrhizal fungus and humic acid application on the growth of Parkinsonia aculeata $\mathbf{L}$. seedlings
}

\author{
Marwa G. S. Frahat ${ }^{1}$,Ahmed A. A. El-Settawy ${ }^{1}$, and Mohamed R. A. Shehata ${ }^{2}$ \\ ${ }^{1}$ Forestry and Wood Technology Department, Faculty of Agriculture, Alexandria University. \\ ${ }^{2}$ Plant Pathology Departments, Faculty of Agriculture, Alexandria University.
}

\section{BSTRACT}

The study is aimed at investigating the influence of mycorrhizal fungus and humic acid (HA) on the growth of Parkinsonia aculeata L. seedlings. The experiments were carried out during the period from July, $1^{\text {st }}, 2017$ to March, $1^{\text {st }} 2018$. The inoculation with mycorrhiza was applied to the seedlings at age of 2 months. Two types of soils were used in this study as follows: a) a mixture of sand, peat and perlite at the ratio of $1: 1: 1$, by volume, and b) clayey soil. Humic acid (HA) was applied just after seed sowing at the rate of $1 \mathrm{~g} / \mathrm{L}(200 \mathrm{ml}$ pots). The obtained results showed that there were significant differences between the two soil types tested. However, the seedlings grown in clayey soil displayed the highest shoot height $(\mathrm{SH})(47.44 \mathrm{~cm})$, the highest shoot dry weight (SDW) (2.40g), the highest total dry weight (TDW) (3.59g) and the highest shoot/ root ratio (SRR) (2.26). The inoculation with VAM has brought about the highest SH $(34.66 \mathrm{~cm})$, SDW (1.76g), TDW (1.76g), P\% (1.81) and N\% (2.73) in the leaves. However, the highest TDW was obtained in the inoculated seedlings treated with HA acid and grown on clayey soil $(4.498 \mathrm{~g})$. The highest $\mathrm{P} \%$ was obtained in the inoculated seedlings of $P$. aculeata grown on clayey soil and untreated with HA (3.94 P\%). Therefore, it is recommended to inoculate the seedlings with VAM to achieve the highest growth and performance as an important nursery practice in afforestation and windbreaks program and in poor soils as well.

\section{Keywords: Mycorrhiza, VAM, Humic acid, Parkinsonia.}

\section{INTRODUCTION}

Palo verde (Parkinsonia aculeata), is spiny shrub or a small tree, which grows 2 to $8 \mathrm{~m}$ (6.6 to

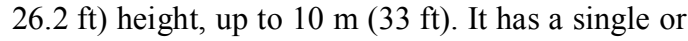
multiple stems and many branches with pendulous leaves. The leaves and stems are hairless. The leaves are alternate and pinnate (15 to $20 \mathrm{~cm}$ long). The flattened petiole is edged by two rows of 25 30 tiny oval leaflets; the leaflets are soon deciduous in dry weather (and during the winter in some areas) leaving the green petioles and branches as a main photosynthesizer part of the tree (Sandro, 1982).

The branches are of double or triple sharp strong spines, $7-12 \mathrm{~mm}(0.28-0.47 \mathrm{in})$ long at the axils of the leaves. The flowers are yellow- orange and fragrant, $20 \mathrm{~mm}$ (0.79 in) in diameter, growing from a long cylender stalk in groups of eight to ten. They have five sepals and five petals, four of them clearer and rhomboid ovate, the fifth elongated, with a warmer yellow and purple spots at the base. The tree is flowering in midspring or autumn. The flowers are usually pollinated by the bees. The fruit is a seedpod, leathery in appearance, light brown when mature (Greenway, 2000).

Parkinsonia aculeata is high tolerant to drought, simply attaining shorter stature. In moist and humus-rich environment, it becomes taller, spreading shade. This plant prefers a full sun exposure and can grow on a wide range of dry soils (sand dunes, clayey, alkaline and chalky soils,etc.), at an altitude of $0-1,500$ metres $(0-4,921 \mathrm{ft})$ above sea level (Sandro, 1982).

Parkinsonia aculeata is used for firewood, charcoal, medicine, fodder (pods and leaves), shade, mulch and as a live fence. It is useful in soil stabilization as windbreaks (Henderson, 2001).

Humic acids are the main components or fractions of HA substances (HS) and the most active components of soil and compost organic matter. HA can enhance nutrient availability and improve chemical, biological, and physical soil properties (Nardi, et al., 2002 , Selim and Mosa 2012 ). There are direct and indirect beneficial effects of HA on plant growth and development, notably, on cell membranes which lead to the enhanced transport of minerals, improved protein synthesis, plant hormone-like activity, promoted photosynthesis, modified enzyme activities, solubility of micro-elements and macro-elements, reduction of active levels of toxic minerals and increased to extant beneficial microbial populations (Hamideh, et al., 2013.)

Arbuscular mycorrhizae (AM) are characterized by the formation of unique structures, arbuscules and vesicles by fungi of the Phylum: Glomeromycota. AM fungi help plants to capture nutrients such as phosphate, sulfur, nitrogen and micronutrients from the soil ( Smith and Smith 2010a). It is believed that the development of the 
arbuscular mycorrhizal symbiosis played a crucial role in the initial colonization of land by plants and in the evolution of the vascular plants (Brundrett, 2002 , Sally et al., 2011 and smith and smith 2011).

It has been said that it is quicker to list the plants that do not form mycorrhizae than those that do. This symbiosis is a highly evolved mutualistic relationship found between fungi and plants, the most prevalent plant symbiosis known (Simon, et al., 1993) . Moreover, AM is found in $80 \%$ of vascular plant families in existence today ( Schüßler et al., 2001).

\section{The objectives of this study were:}

1- Studying the effect of mycorrhiza inoculation and HA on growth characteristics of Parkinsonia aculeata $L$. seedlings.

2- Investigating the effect of soil types on the growth of Parkinsonia aculeata, to pinpoint the best recommended treatment for getting best germination level and growth performance of the plant in situ.

\section{Materials and Methods}

This study was conducted at the nursery of Forestry and Wood Technology Dept. of the Experimental Station of Faculty of Agriculture, University of Alexandria, Abies region, Alexandria. The study aimed at investigating the influence of mycorrhizal fungus and $\mathrm{HA}$ acid on growth of Parkinsonia aculeata $L$. seedlings. The experiments were carried out during the period from July $1^{\text {st }}, 2017$ to March, $1^{\text {st }} 2018$.

\subsection{The plant material}

The seeds of Parkinsonia aculeata L. were collected from 20 years old trees grown at the Experimental Station of Faculty of Agriculture, University of Alexandria, Abies region, Alexandria.

\subsection{Soil}

The soils used in this study were: a) A mixture of sand, peat and perlite at the ratio of $1: 1: 1$, by volume, and b) Clayey soil.

The soils were treated with $20 \%$ formaldehyde solution and left for 10 days for aeration.

\subsection{Symbiotic agents}

2.3.1. Vesicular arbuscular mycorrhizal fungus (VAM)

Inocula implied clamydospores of Glomus fasciculatum and infected root debris with the fungus were obtained originally from the Experimental Station of Philipps University, Botany, Dept. Marburg/ Lahn, Germany.

\subsection{Experimental procedure}

On August, $8^{\text {th }} 2017$, seeds of Parkinsonia aculeata $L$. were sown in plastic bags, filled with $2.0 \mathrm{~kg}$ of 1:1:1 sand, peat and perlite (v:v:v) and ca
$3.5 \mathrm{~kg}$ of clayey soil, except for the upper $3 \mathrm{~cm}$ from the rim. Surface sterilized seeds (4 seeds per pot) with $10 \% \mathrm{NaHCl}$ were sown then $\mathrm{HA}$ was applied using $1 \mathrm{~g} / \mathrm{L}(200 \mathrm{ml} \backslash$ pots $)$. After germination of seeds, the mycorrhiza inoculum was applied to the seedlings at the age of 2 months. The amount used was $3.0 \mathrm{~g} /$ plant, containing 50 chlamydospores of VAM.

\subsection{Medium analysis}

The chemical and physical properties of the medium were determined as follows:

The electrical conductivity (EC) of the saturated medium paste extract by using conductimeter GLP 31 and the $\mathrm{pH}$ of the medium was measured for the saturated medium-water suspension using $\mathrm{pH}$-meter GLP 21. Water soluble ions were determined in the saturated medium paste extract. Calcium and magnesium were determined by versenate method, while sodium and potassium were determined by a flame photometer. Bicarbonate and carbonate were determined by titration with dilute hydrochloric acid and chloride by silver nitrate method (Richard, 1954) and total carbonate in the medium was measured by calcimeter method (Page et al., 1982). The organic matter content of the medium was determined according to Wakely and Black method (Page et al., 1982).

Available nitrogen was determined or assayed by the extraction with $0.1 \mathrm{M}$ potassium chloride and then determined by Kjeldahle method (Page et al., 1982). Available phosphorus was extracted with sodium bicarbonate method and the concentration of phosphorus was determined colorimetrically by a spectrophotometer (Olsen and Sommers, 1982). Available potassium was extracted with neutral normal ammonium acetate and the concentration of potassium was determined using a flame photometer (Chapman and Pratt, 1961). Available copper $(\mathrm{Cu})$, manganese $(\mathrm{Mn})$, zinc $(\mathrm{Zn})$, nickel $(\mathrm{Ni})$, cadmium $(\mathrm{Cd})$ and lead $(\mathrm{Pb})$ were determined by extraction by DTPA-reagent and the concentrations of metals were measured by an atomic absorption spectrophotometer (Page $\boldsymbol{e t}$ al., 1982). The particle size distribution (sand, silt and clayey) was determined by the hydrometer method (Black, 1965).

\subsection{Growth parameters}

Growth parameters, i.e., seedlings height $(\mathrm{cm})$, dry weight of the seedling $(\mathrm{g})$, shoot/ root ratio, shoot growth rate $(\mathrm{cm} /$ month), and root length $(\mathrm{cm})$ were determined. At the end of the experiment, seedlings were extraced carefully from the polyethylene bags, then the roots were washed gently with a tap water. Each seedling was cut into root and shoot (leaves and stem) and their fresh weights were determined then oven-dried at $70^{\circ} \mathrm{C}$ for 48 hours to a constant weight, to determine the dry weight of each plant part. 


\subsection{Determination of the VAM -infection level.}

\subsubsection{Ultrastructural examination of} infected feeder roots with VAM

Feeder -root samples were collected, washed free from debris, cut into small pecies $(3 \mathrm{~mm}$ length) then soaked in chain of ethanol solutions, 50, 70, 90 and $100 \%$ (absolute alkohol) then in mixture of alcohol and xylene $(1: 1, \mathrm{~V}: \mathrm{V})$ eventually in pure xylene solution. The specimens were soaked in each concentration for 1.0 hour, dried and fixed for scanning electron microscope (SEM) examination, according the method described by Hayat, (1991).

\subsection{Determination of mineral concentration of the plants}

Samples of the leaves, stems and roots of the seedlings were dried, ground in Wiley mill to a fine powder and stored in plastic bags for analysis.

A half gram of the oven-dried plant material powder was digested by $2.5 \mathrm{ml}$ concentrated sulphuric acid $\left(\mathrm{H}_{2} \mathrm{SO}_{4}\right)$ and poured in a hot plate at approximately $270^{\circ} \mathrm{C}$. Few drops of $30 \%$ hydrogen peroxide were repeatedly added until a clear digest was obtained. The solution was left to cool, filtered and diluted to $50 \mathrm{ml}$ with distilled water (Cottenie, 1980). The digested samples were prepared for measuring total nitrogen, phosphorus and potassium.

Nitrogen was determined by Kjeldahle method and phosphorus was determined by the colorimetric method (Olsen and Sommers, 1982). Potassium was determined by a flame photometer according to the method described by Chapman and Pratt, (1961). The cocentaration of N, P and $K$ in plant samples were calculated as a percentage on dry weight basis.

\subsection{The experimental design}

A complete randomized design (CRD) was used in this experiment. The split plot technique was used in analyzing the obtained data, where the main plot was for soil type, the sub plot for a HA acid treatment and the sub-sub plot was for the impact of the inoculation with symbiotic agent according to Snedecor (1956) using SAS ver. 9.1.3 (2007).

Four replications were used for each treatment. The outline of source of variance is set out in Table (1).
Table1: Outline of the source of variation and its degree of freedom (d.f) of the experiment used.

\begin{tabular}{ll}
\hline \multicolumn{1}{c}{ source of variance } & d.f \\
\hline Replicates & 3 \\
\hline $\mathrm{A}$ & 1 \\
\hline Error a & 3 \\
\hline $\mathrm{B}$ & 1 \\
\hline $\mathrm{AB}$ & 1 \\
\hline $\mathrm{C}$ & 1 \\
\hline $\mathrm{AC}$ & 1 \\
\hline $\mathrm{BC}$ & 1 \\
\hline $\mathrm{ABC}$ & 1 \\
\hline Experimental error & 18 \\
\hline Total & 31 \\
\hline
\end{tabular}

\section{Results}

\subsection{Mycorrhization}

The scanning electron microscope examination has revealed the presence of appressorium and extrametrical hyphae as shown in (Fig.1).

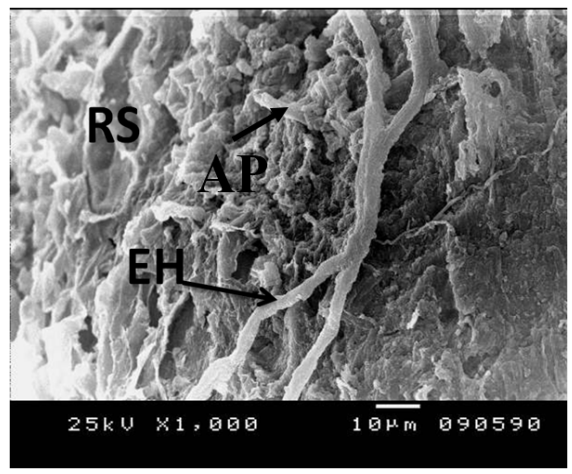

Fig. 1: Scanning electron micrograph indicates root surface (RS) penetrated by extrametrical hyphae of VAM fungus (EH) and AP is a appressorium of the fungus.

\subsection{Growth parameters}

\subsubsection{Shoot height SH (cm)}

There were significant differences between soil types, the highest $\mathrm{SH}$ was obtained in the seedlings grown on clayey soil $(47.44 \mathrm{~cm})$, whilst the lowest value was found in those grown on sandy peat mixture soil $(16.85 \mathrm{~cm})$ (Table 2).

As for the effect of inoculation with the symbiotic agents, it was found that the inoculated seedlings with VAM exhibited the highest $\mathrm{SH}$ $(34.66 \mathrm{~cm})$ (Table, 2). Furthermore, the statistical analysis has also revealed significant interaction between HA application and VAM inoculation and the triple interaction among soil type, HA application and VAM inoculation. 
Table2: Shoot height (cm) of uninoculated (C) and inoculated seedlings of Parkinsonia aculeata with vesicular-arbuscular mycorrhizal fungi (VAM )grown on two types of soil

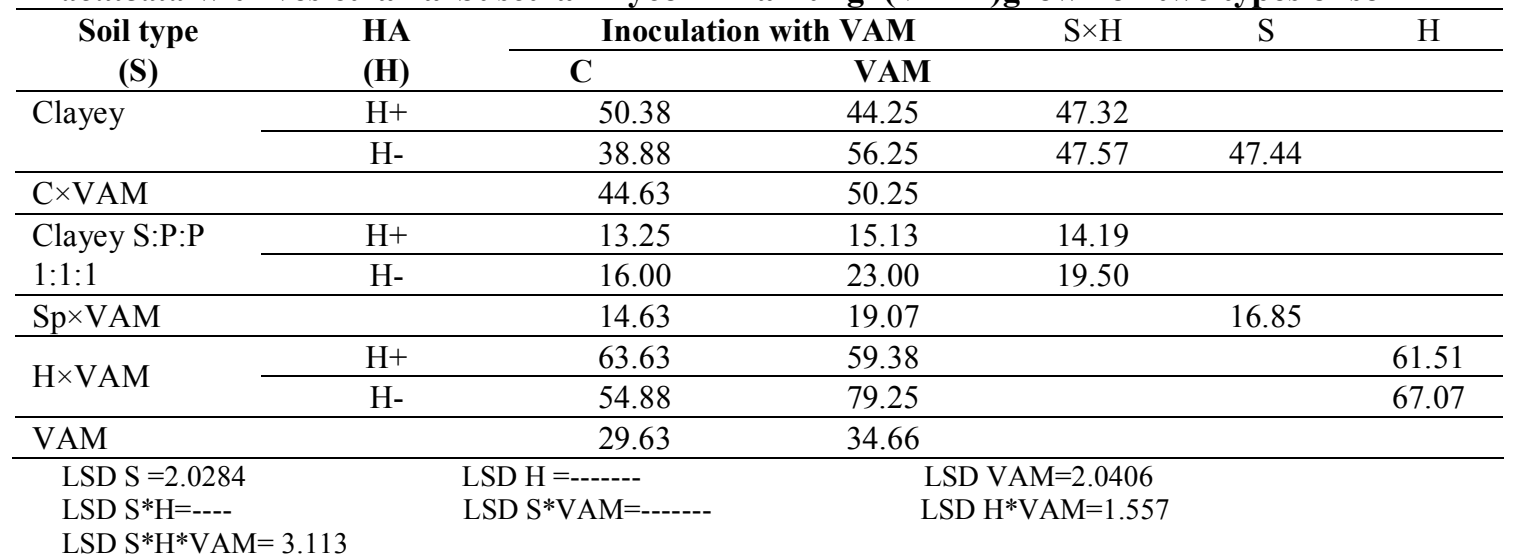

\subsubsection{Shoot dry weight (SDW) (g)}

It was found that the seedlings grown on clayey soil displayed the highest SDW (2.40g) which averaged as much 3.5 fold as that in sand-peat mixture $(0.68 \mathrm{~g})$. The inoculation with VAM has also brought about the highest SDW $(1.76 \mathrm{~g})$, while uninoculated seedlings displayed the lowest value of SDW, since it was $1.33 \mathrm{~g}$ (Table, 3). Furthermore, the significant interaction between soil type and VAM inoculation has manifested that the seedlings grown on clayey soil and inoculated with VAM fungus displayed the highest SDW $(2.82 \mathrm{~g})$, followed by uninoculated seedlings with VAM which grown on the same soil type $(1.98 \mathrm{~g})$ (Table, 3).

As for the significant triple interaction of the factors studied, it was found that the seedlings inoculated with VAM which grown in calcareous soil and amended with HA acid displayed the highest SDW, since it was $3.18 \mathrm{~g}$, which considered as much 5 fold as that of the control $(0.61 \mathrm{~g})$.

\subsubsection{Total dry weight (TDW) (g)}

Seedlings grown on clayey soil displayed the highest TDW $(3.59 \mathrm{~g})$, while the seedlings grown on sand - peat mixture recorded $1.2 \mathrm{~g}$ (Table 4).

As for the effect of inoculation with symbiotic agent, there were significant differences among uninoculated seedlings (control) and inoculated ones with symbiotic agent under study. It was found that the inoculated seedlings had the highest TDW (2.602g) (Table 4).

Finally, there was a significant interaction among the three factors studied. However, the highest TDW was obtained in the inoculated seedlings which applied with HA and grown on clayey soil $(4.498 \mathrm{~g})$, followed by VAM inoculated ones grown on sand peat mixture $(0.915 \mathrm{~g})(2.18 \mathrm{~g})$ (Table 4).

\subsubsection{Shoot/ root ratio (SRR)}

As for, soil type the seedlings grown on clayey soil indicated that the highest SRR (2.26).

The significant interaction between soil type and HA application indicated that the seedlings grown on clayey soil and untrated with HA acid displayed the highest SRR (2.76), yet the seedlings grown on the same soil and treated with HA acid displayed the lowest SRR (1.85) (Table, 5).

Finally, the significant triple interaction among soil type, HA application and symbiosis type manifested that the uninoculated seedlings grown on clayey soil and untreated with HA displayed the highest SRR (3.32), whilst the lowest value (1.06) was obtained for those uninoculated ones grown on the same soil and treated with HA (Table, 5).

\subsubsection{Root dry weight (RDW) (g)}

There were significant effects of the soil type. However, seedlings grown on clayey soil displayed the highest RDW (1.19g) (Table, 6).

As for, the effect of inoculation mycorrhizal fungus, there were significant differences among uninoculated seedlings (control) and inoculated ones with VAM, the inoculated seedlings displayed the highest value of RDW (1.68g) (Table, 6).

\subsection{Mineral concentration in the flattered mid-rib (leaves)}

\subsubsection{Nitrogen (N\%)}

Regardless HA application and symbiosis type, seedlings grown on clayey soil displayed the highest $\mathrm{N} \%$ in their leaves $(2.76 \%)$ as compared with those grown on sand-peat perlite mixture $(1.50 \%)$ (Table 7$)$.

However, the inoculated seedlings with VAM contained the highest $\mathrm{N} \%(2.73 \mathrm{~N} \%)$ as compared with the uninoculated ones, since it was $1.53 \%$ (Table,7). 
Table3: Shoot dry weight (g) of uninoculated (C) and inoculated seedlings of Parkinsonia aculeata with vesicular-arbuscular mycorrhizal fungi (VAM)grown on two types of soil

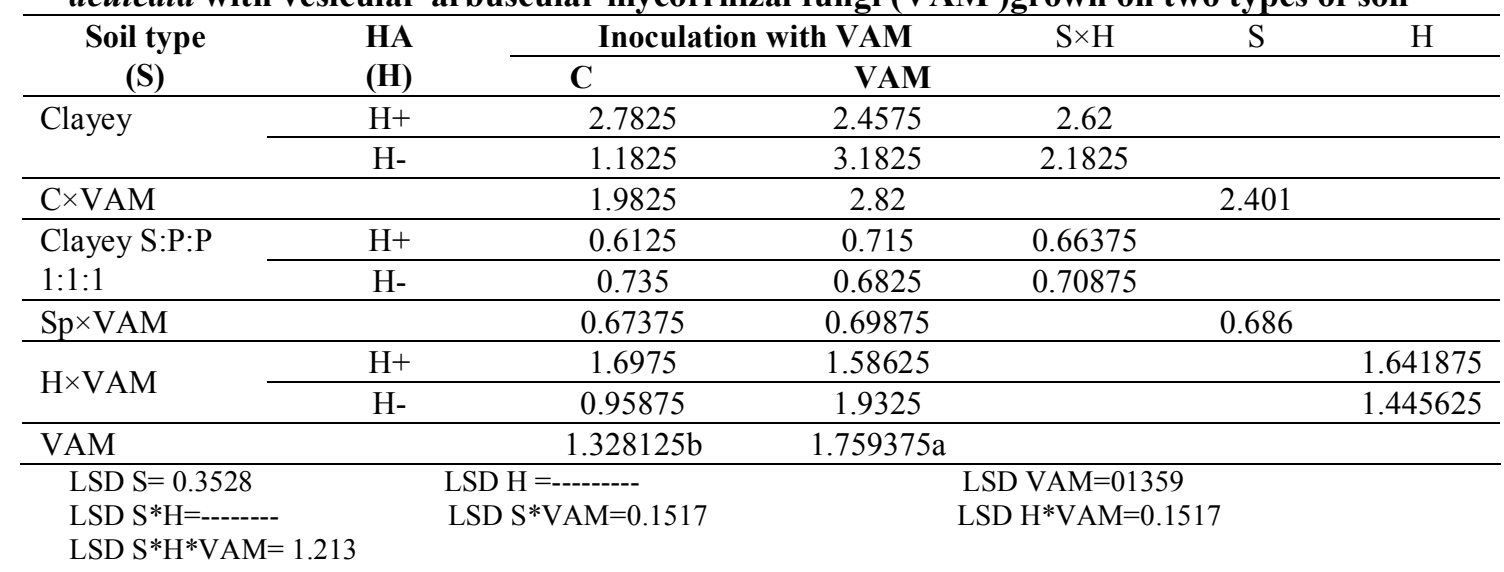

Table4: Total dry weight (g) of uninoculated (C) and inoculated seedlings of Parkinsonia aculeata with vesicular-arbuscular mycorrhizal fungi (VAM)grown on two types of soil

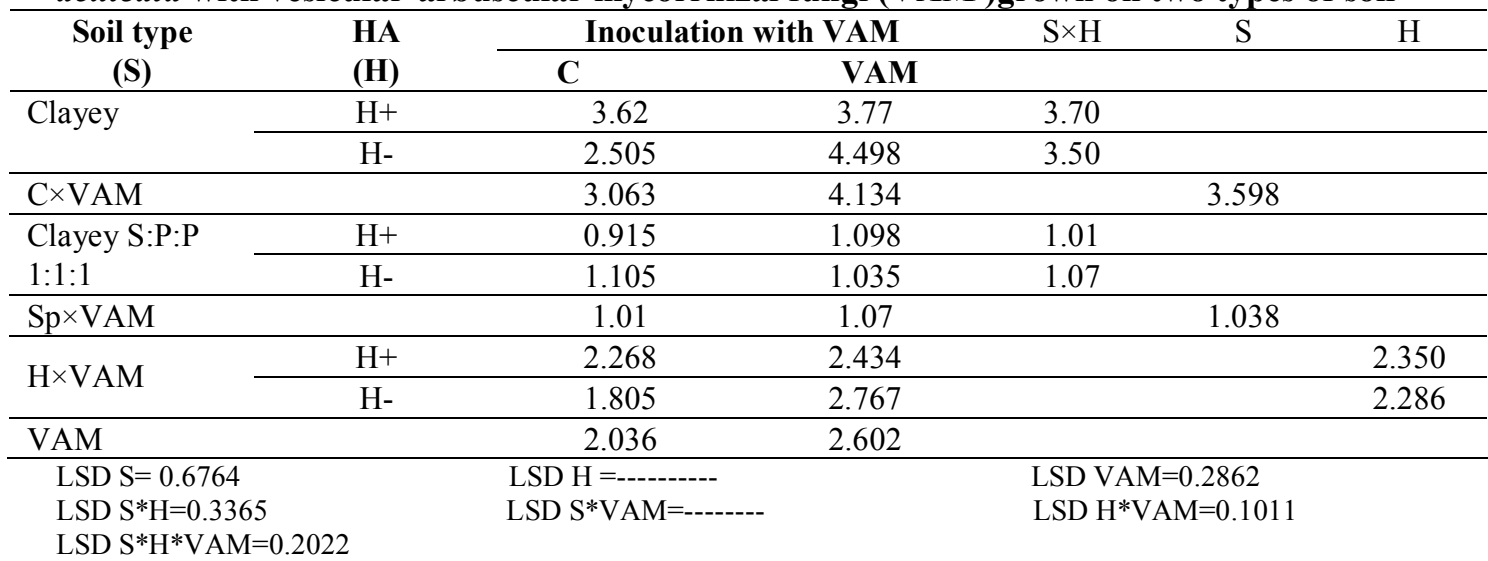

Table5: Shoot root ratio of uninoculated (C) and inoculated seedlings of Parkinsonia aculeata with vesicular-arbuscular mycorrhizal fungi (VAM)grown on two types of soil

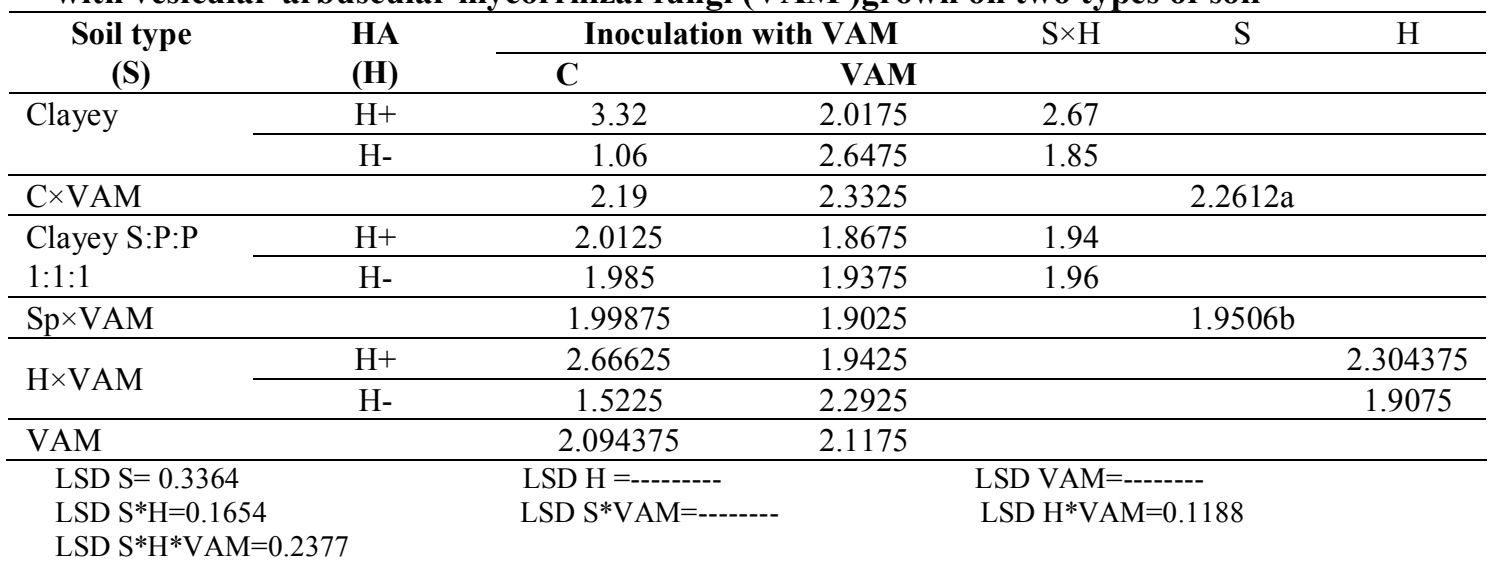


Table6: Root dry weight (g) of uninoculated (C) and inoculated seedlings of Parkinsonia aculeata with vesicular-arbuscular mycorrhizal fungi (VAM)grown on two types of soil

\begin{tabular}{|c|c|c|c|c|c|c|}
\hline \multirow{2}{*}{$\begin{array}{l}\text { Soil type } \\
\text { (S) }\end{array}$} & \multirow{2}{*}{$\begin{array}{l}\text { HA } \\
\text { (H) }\end{array}$} & \multicolumn{2}{|c|}{ Inoculation with VAM } & \multirow[t]{2}{*}{$\mathrm{S} \times \mathrm{H}$} & \multirow[t]{2}{*}{$\mathrm{S}$} & \multirow[t]{2}{*}{$\mathrm{H}$} \\
\hline & & C & VAM & & & \\
\hline \multirow[t]{2}{*}{ Clayey } & $\mathrm{H}+$ & 0.838 & 1.313 & 1.076 & & \\
\hline & $\mathrm{H}-$ & 1.323 & 1.315 & 1.319 & & \\
\hline $\mathrm{C} \times \mathrm{VAM}$ & & 1.080 & 1.314 & & $1.19^{\prime}$ & \\
\hline \multirow{2}{*}{$\begin{array}{l}\text { Clayey S:P:P } \\
1: 1: 1\end{array}$} & $\mathrm{H}+$ & 0.303 & 0.383 & 0.343 & & \\
\hline & $\mathrm{H}-$ & 0.370 & 0.353 & 0.362 & & \\
\hline $\mathrm{Sp} \times \mathrm{VAM}$ & & 0.337 & 0.368 & & 0.35 & \\
\hline \multirow{2}{*}{$\mathrm{H} \times \mathrm{VAM}$} & $\mathrm{H}+$ & 1.141 & 1.696 & & & 1.419 \\
\hline & $\mathrm{H}-$ & 1.693 & 1.668 & & & 1.680 \\
\hline VAM & & 1.417 & 1.682 & & & \\
\hline $\begin{array}{l}\text { LSD } S=0.2357 \\
\text { LSD } S^{*} \mathrm{H}=\end{array}$ & & $\begin{array}{l}\text { LSD H } \\
\text { LSD S* }\end{array}$ & & $\begin{array}{l}\text { LSI } \\
\text { LSI }\end{array}$ & $\begin{array}{l}\mathrm{I}=0.03 \\
\mathrm{AM}=\end{array}$ & \\
\hline
\end{tabular}

Table7:Nitrogen (\%) in the leaves of uninoculated (C) and inoculated seedlings of Parkinsonia aculeata with vesicular-arbuscular mycorrhizal fungi (VAM)grown on two types of soil

\begin{tabular}{|c|c|c|c|c|c|c|}
\hline \multirow{2}{*}{$\begin{array}{l}\text { Soil type } \\
\text { (S) }\end{array}$} & \multirow{2}{*}{$\begin{array}{l}\text { HA } \\
\text { (H) }\end{array}$} & \multicolumn{2}{|c|}{ Inoculation with VAM } & \multirow[t]{2}{*}{$\mathrm{S} \times \mathrm{H}$} & \multirow[t]{2}{*}{$\mathrm{S}$} & \multirow[t]{2}{*}{$\mathrm{H}$} \\
\hline & & $\mathbf{C}$ & VAM & & & \\
\hline \multirow[t]{2}{*}{ Clayey } & $\mathrm{H}+$ & 1.64 & 3.24 & 2.44 & & \\
\hline & $\mathrm{H}-$ & 2.20 & 3.94 & 3.07 & & \\
\hline $\mathrm{C} \times \mathrm{VAM}$ & & 1.92 & 3.59 & & 2.76 & \\
\hline \multirow{2}{*}{$\begin{array}{l}\text { Clayey S:P:P } \\
1: 1: 1\end{array}$} & $\mathrm{H}^{+}$ & 0.58 & 1.72 & 1.15 & & \\
\hline & $\mathrm{H}-$ & 1.71 & 1.99 & 1.85 & & \\
\hline Sp $\times$ VAM & & 1.14 & 1.86 & & 1.50 & \\
\hline \multirow{2}{*}{$\mathrm{H} \times \mathrm{VAM}$} & $\mathrm{H}+$ & 1.10 & 2.48 & & & 1.79 \\
\hline & $\mathrm{H}-$ & 1.96 & 2.97 & & & 2.47 \\
\hline \multicolumn{2}{|l|}{ VAM } & 1.53 & 2.73 & & & \\
\hline \multicolumn{2}{|c|}{$\begin{array}{l}\text { LSD S }=0.2405 \\
\end{array}$} & $\begin{array}{l}\text { LSD H } \\
\text { LSD S }\end{array}$ & & \multicolumn{3}{|c|}{$\begin{array}{l}\text { LSD VAM=0.5701 } \\
\text { LSD H*VAM=---- }\end{array}$} \\
\hline
\end{tabular}

LSD S*H*VAM $=0.6322$

Considering the significant interaction between soil type and HA application, leaves of Parkinsonian aculeata seedlings grown on clayey soil and untreated with HA acid displayed the highest N\% (3.07\%) (Table, 7).

The triple interaction among all studied factors indicated that the inoculated seedlings with VAM and untreated with HA acid, which grown on clayey soil as well as those uninoculated displayed the highest $\mathrm{N} \%$, since it was $3.94 \%$. On the other hand, the uninoculated seedlings and treated with $\mathrm{HA}$ and grown on sand- peat- perlite displayed the lowest N\% (0.58 N\%) (Table 7).

\subsubsection{Phosphorus (P \%)}

As for, soil type the seedlings grown on clayey soil displayed the highest $\mathrm{P} \%(1.81 \%)$ as compared with the other soil, since it was $(0.93 \%)$ (Table, 8$)$.

Regardless mycorrhizal inoculation, there was found significant interaction between soil type and HA application. It is clear that the untreated seedlings with HA grown on clayey soil displayed the highest value of $\mathrm{P} \%$, since it was $2.03 \%$ (Table, $8)$.
Concerning the effect of inoculation with symbiotic agents, there were significant differences among uninoculated seedlings (control) and inoculated ones with VAM since the inoculated seedlings with VAM exhibited the highest $\mathrm{P} \%(2.37$ $\mathrm{P} \%$ ), but uninoculated ones displayed the lowest $\mathrm{P} \%$ value $(0.37 \mathrm{P} \%$ (Table, 8$)$.

The significant triple interaction among all studied factors showed that the highest $\mathrm{P} \%$ was obtained in the inoculated seedlings of $P$. aculeata grown on clayey soil and untreated with HA acid (3.94 $\mathrm{P} \%$ ), followed by inoculated ones grown on the same soil and treated with HA $(2.40 \mathrm{P} \%)$. (Table, 8). 
Table8: Phosphorus (\%) in the leaves of uninoculated (C) and inoculated seedlings of Parkinsonia aculeata with vesicular-arbuscular mycorrhizal fungi (VAM) grown on two types of soil

\begin{tabular}{|c|c|c|c|c|c|c|}
\hline \multirow{2}{*}{$\begin{array}{l}\text { Soil type } \\
\text { (S) }\end{array}$} & \multirow{2}{*}{$\begin{array}{l}\text { HA } \\
\text { (H) }\end{array}$} & \multicolumn{2}{|c|}{ Inoculation with VAM } & \multirow[t]{2}{*}{$\mathrm{S} \times \mathrm{H}$} & \multirow[t]{2}{*}{$\mathrm{S}$} & \multirow[t]{2}{*}{$\mathrm{H}$} \\
\hline & & $\mathbf{C}$ & VAM & & & \\
\hline \multirow[t]{2}{*}{ Clayey } & $\mathrm{H}+$ & 0.786 & 2.40 & 1.59 & & \\
\hline & $\mathrm{H}-$ & 0.117 & 3.94 & 2.03 & & \\
\hline $\mathrm{C} \times \mathrm{VAM}$ & & 0.45 & 3.17 & & 1.81 & \\
\hline \multirow{2}{*}{$\begin{array}{l}\text { Clayey S:P:P } \\
1: 1: 1\end{array}$} & $\mathrm{H}+$ & 0.118 & 1.54 & 0.83 & & \\
\hline & H- & 0.453 & 1.61 & 1.03 & & \\
\hline $\mathrm{Sp} \times \mathrm{VAM}$ & & 0.29 & 1.58 & & 0.93 & \\
\hline \multirow{2}{*}{$\mathrm{H} \times \mathrm{VAM}$} & $\mathrm{H}+$ & 0.452 & 1.97 & & & 1.211 \\
\hline & H- & 0.285 & 2.775 & & & 1.53 \\
\hline \multicolumn{2}{|l|}{ VAM } & 0.37 & 2.37 & & & \\
\hline \multicolumn{2}{|c|}{$\begin{array}{l}\text { LSD S }=0.2405 \\
\text { LSD } S * H=0.0082\end{array}$} & \multicolumn{2}{|c|}{ LSD H =-------- } & \multicolumn{2}{|c|}{ LSD VAM=1.5703 } & \\
\hline \multicolumn{2}{|c|}{ LSD $\mathrm{S} * \mathrm{H} * \mathrm{VAM}=1.4368$} & LSD S & & LSD & & \\
\hline
\end{tabular}

\section{Discussion}

The obtained results showed that the inoculation with VAM led to enhance the growth significantly, in terms of SH, SRR, RDW, SDW and minerals of the leaves of P. aculeata ( $\mathrm{N} \%$ and $\mathrm{P} \%$ ) compared with the uninoculated ones, owing to the ability of mycorrhiza to increase root surface area to uptake mineral contents and make phosphorus more available to be absorbed by plant roots. Growth would be enhanced both by increasing the $\mathrm{pH}$ and by inoculating with the VAM fungi, with plant responses greater with inoculation (Smith et al., 2004).

The high degree of mycorrhizal colonization in the roots of soil pH ranging from 5.5 to 7.5 (Soti $e t$ al. 2014). Also, differs between inter the genera of mycorrhiza. Furthermore, mycorrhizal fungi can modify the soil $\mathrm{pH}$ in the rhizosphere (Jones et al. 2004), and in most cases, it induced the decrease in soil $\mathrm{pH}$ (McNear 2013), which bring about the solubility of minerals of the soil, notably phosphorus and some heavy metals.

In this study, there was an evidence for the negative effect of HA on the mycorrhization and seedlings biomass. Francois (1993) manifested that respiration of the two fungi (Cenococcum gratiforme and Laccaria laccata) was inhibited by the four phenolic acids from HA solutions which have biological activity at extremely low concentrations. The understanding of the ecological control by dissolved HA substances is still fragmentary and needs to be studied in more details (Christian, et al., 2008).

Dry weight yields and mineral concentration of plants inoculated with Glomus fascieculatum, which grown on clayey soil was significantly higher than those of Mycorrhhizal ones grown on the sand-peat mixure, that may be ascribed to the increasing EC in the clayey soil $\left(2.81 \mathrm{dS} \mathrm{m}^{-1)}\right.$ which accounted for 2 fold of that in the soil mixture $\left(1.36 \mathrm{dS} \mathrm{m}^{-1}\right)$.

However, few studies have demonstrated that the ability of different species of mycorrhizal fungi to increase plant growth also differs with soil $\mathrm{pH}$. The effects of soil $\mathrm{pH}$ on the growth of uninoculated and inoculated Eucalyptus globulus highlights the importance of determining the mycorrhizal status of plants when examining the effects of soil factors such as $\mathrm{pH}$ on plant growth (Thomson et al., 1996).

Until recently the functioning of AM at low $\mathrm{pH}$ was generally studied by growing plants with and without inoculation in acid soils differing naturally in $\mathrm{pH}$ (Clark and Zeto, 1996) or acid soils limed to achieve different $\mathrm{pH}$ (Raju et al., 1988 and Nurlaeny et al., 1996). Using these methods, some interesting data on the effects of low $\mathrm{pH}$ on the functions of AM symbiosis have been obtained, but it is hardly ever possible to identify factors responsible for measured outcomes, due to the variability of soil components used in these studies (Sunita, et al., 2011).

Inoculation of Eucalyptus globulus with the ectomycorrhizal isolates tested increased the uptake of $\mathrm{P}$ and growth of plants under different levels of soil pH (Thomson et al., 1996).

The ability of VAM fungi to colonize plant roots differed and was affected differently by $\mathrm{pH}$. Percentages of root length colonized by Glomus etunicatum were significantly lower than those colonised by Gigaspora margarita. Decreasing the initial $\mathrm{pH}$ from 5.2 to 4.7 significantly depressed the ability of G. etunicatum to colonize plant roots, but did not affect Gi. margarita. No AM colonization was observed in roots of non mycorrhizal plant and as it expected, there was no nodulation on roots of any plants (Smith et al., 2004). 


\section{Conclusion and Recommendations}

The inoculation with VAM significantly enhanced the growth (in terms of shoot height, shoot root ratio, shoot dry weight and total dry weight) of Parkinsonia aculeata seedlings. The mycorrhization and growth of seedlings on clayey soil was rather better or distinct as compared to that in the mixture of sand: peat: perlite. The negative impacts of the Parkinsonia aculeata to application with HA, were noticed in terms of all growth parameters, $\mathrm{P}$ and $\mathrm{K}(\%)$.

It is recommended; however, to inoculate the seedlings with VAM to enhance its growth and performance as an important nursery practice in windbreaks programs, even though in poor soils.

\section{Literature cited}

Black, C. A. 1965. Methods of Soil Analysis. Parts 1 and 2. Agronomy of Soc. Agron Madison; WL 802 pp.

Bundrett, 2002. Coevolution of roots and myconhizase of 1 and plants. NewPhytologist 154: 275-304.

Chapman, H.D. and Pratt, P.F. 1961. Methods of Analysis for Soils, Plants and Waters. Agric. Pub. Univ. of California, Riverside, USA.

Christian E. W. Steinberg, Thomas Meinelt Maxim A., Timofeyev, Michal Bittner and Ralph Menzel. 2008. HA substances, Environmental Science and Pollution Research. 15:128.

Clark $R \quad B$ and Zeto $S$ K. 1996. Mineral acquisition by mycorrhizal maize grown on acid soil and alkaline soil. Soil Biol. Biochem. 28, 1495-1503.

Cottenie, A. (1980). Soil and Plant Testing as a Basis of Fertilizer Recommendations. F.A.O. No. (38/2). Methods of Plant Analysis. Wet Destruction, 94-95.

Francois Pellissier.1993. Allelopathic effect of phenolic acids from HA solutions on two spruce mycorrhizal fungi:Cenococcum graniforme and Laccaria laccata, Journal of Chemical Ecology, 19, 2105-2114.

Greenway, Theresa. 2000. The Plant Kingdom: A Guide to Plant Classification and Biodiversity. Texas: Steck- Vaughn Company.

Hamideh G., Samavat S. and Ardebili. Z. O. 2013. The alleviating effects of HA substances on photosynthesis and yield of Plantago ovata in salinity conditions, International Research Journal of Applied and Basic Sciences, 4, (7): 1683-1686.

Hayat, M. A. 1991. Principles and Techniques of Scanning Electron Microscopy, Van Nostrand Reinhold.

Henderson, L. 2001. Alien weeds and invasive plants. A complete guide to declared weeds and invaders in South Africa. Plant Protection
Research Institute Handbook No. 12, 300pp. PPR, ARC South Africa.

Jones DL, Hodge A and Kuzyakov Y (2004) Plant and mycorrhizal regulation of rhizodeposition. New Phytol 163(3):459-480.

McNear Jr., D. H. (2013). The Rhizosphere Roots, Soil and Everything In Between. Nature Education

Nardi S, Pizzeghello D, Muscolo A. and Vianello A., 2002. Physiological effects of HA substances on higher plants, Soil Biochemistry., vol. 34, pp. $1527-1536$

Nurlaeny N, Marschner H and George E. 1996. Effects of liming and mycorrhizal colonization on soil phosphate depletion and phosphate uptake by maize (Zea mays L.) and soybean (Glycine $\max$ L.) grown in two tropical acid soils. Plant Soil, 181: 275-285.

Olsen, S.R.; and Sommers, L.E. 1982. Phosphorus. In: Page, R. H. A. L. Miller and Keeny. D. R. (eds.). Methods of Soil Analysis, (part 1). American Society of Agronomy, Madison, Wisconsin, USA.

Page, A.L.; Miller R.H. and Keeney eds, D.R., 1982. Methods of Soil Analysis. Part 2. American Society of Agronomy, Madison, W.L. Phytopathol.

Raju P S, Clark R B, Ellis J L and Maranville J W. 1988. Effects of VA mycorrhizae on growth and mineral uptake of sorghum grown at varied levels of soil acidity. Commun. Soil Sc. Plant Anal. 19, 919-931.

Richard, L.D. (Ed.). 1954. Diagnosis and Improvement of Saline and Alkali Soils. USDA Handbook 60; Gont. Printing Office, Washington, D. C.

Sally E. Smith, Iver Jakobsen, Mette Grønlund, and F. Andrew Smith.2011. Roles of Arbuscular Mycorrhizas in Plant Phosphorus Nutrition: Interactions between Pathways of Phosphorus Uptake in Arbuscular Mycorrhizal Roots Have Important Implications for Understanding and Manipulating Plant Phosphorus Acquisition. Plant Physiology. Vol. 156, pp. 1050-1057.

Sandro Pignatti. 1982. Flora d'Italia . Edagricole . Vol. I, pag. 625.

SAS Institute Inc. (2007). SAS Technical report SAS/STAT software: Changes and Enhancements Users Guide, Volume 2, Version 9.1.3, Fourth Edition, Gary, NC: SAS Institute Inc.

SchüBler, A., Schwarzott, D. and Wallker, C. 2001. A new fungal phylum, the Glomeromycota: phylogeny and evolution. Mycol. Res. 105 (12): 1416.

Selim, E. M. and Mosa, A. A. 2012. Fertigation of HA substances improves yield and quality of broccoli and nutrient retention in a sandy soil, J. Plant Nutr. Soil Sci., vol. 175, pp. 273-281. 
Selim, E. M., Mosa, A. A., El-Ghamry, A. M., 2009. Evaluation of HA substances fertigation through surface and subsurface drip irrigation systems on potato grown under Egyptian sandy soil conditions, Agr. Water Manage., vol. 96, pp. 1218-1222.

Simon L, Levesque RC, Lalonde M.1993. Identification of endomycorrhizal fungi colonizing roots by fluorescent single-strand conformation-polymerase

chain reaction. Applied and Environmental Microbiology. 59, 4211-4215.

Smith S.E.; Rohyadi A.; Smith F.A. and Murray R.S. 2004. Effects of $\mathrm{pH}$ on mycorrhizal colonisation and nutrient uptake in cowpea under conditions that minimise confounding effects of elevated available aluminium.Plant and Soil. V 260 pp 283-290.

Smith, F. A. and Smith, S. E. 2011. What is the significance of the arbuscular mycorrhizal colonization of many economically important crop plants? Plant Soil, 348: 63-79.

Snedecor, G. W. 1956. Statistical Methods. The Iowa State Univ. Press Ames, Iowa; U.S.A.

Soti PG, Jayachandran K, Purcell M, Volin JC, Kitajima K. 2014. Mycorrhizal symbiosis and Lygodium microphyllum invasion in south Florida - a biogeographic comparison. Symbiosis, 62 (2):81-90

Sunita Kaushis: Aditya Kumar and Ashok Aggarwal. 2011. Influence of hosts and substrates on mass multiplication of Glomus mosseae. African Journal of Agricultural Research 6(13), 2971-2977.

Thomson, B.D.; Grove, T.S.; Malajczuk, N. and Hardy, G.E.StJ. 1996. The effect of soil $\mathrm{pH}$ on the ability of ectomycorrhizal fungi to increase the growth of Eucalyptus globulus Labill. Plant and Soil 178: 209-214.

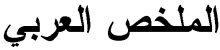

\section{تأثير فطر الميكوريزا الحويصلية الشجرية وإضافة حمض الهيوميك علي نمو شتلات الباركينسونيا أكيو لانا}

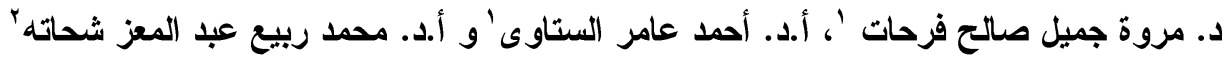
ا قسم الغابات وتكنولوجيا الأخشاب - كلية الزر اعة - جامعة الإسكندرية r ب قسم أمر اض النبات- كلية الزراعة - جامعة الإسكندرية

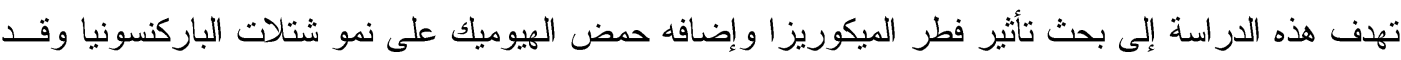

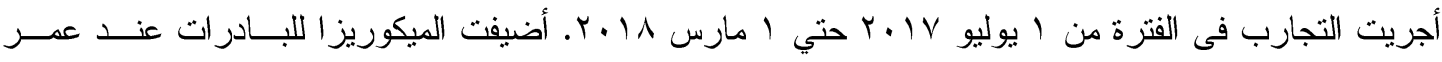
شهرين و استخدم نوعان من الأر اضى فى هذه الدراسة هما: أ- خليط من الرمل و البيتموس و البيرليت بنسبة 1: 1: 1:

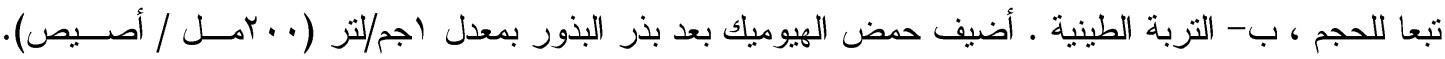

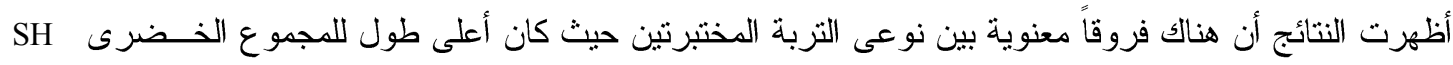

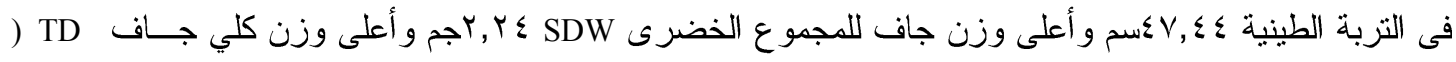

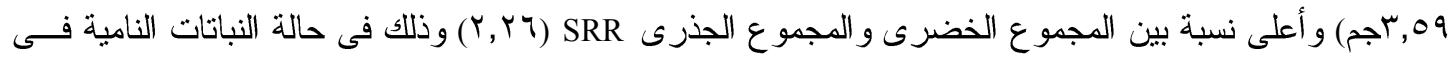

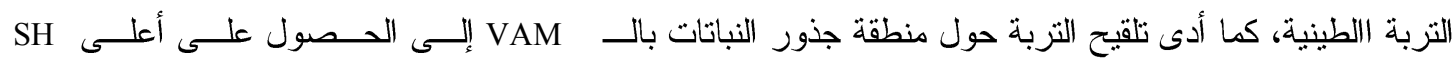

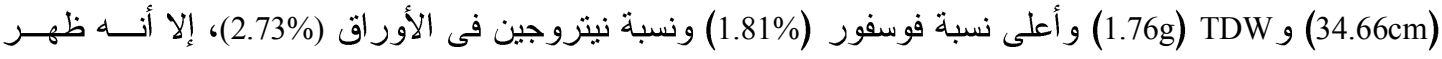

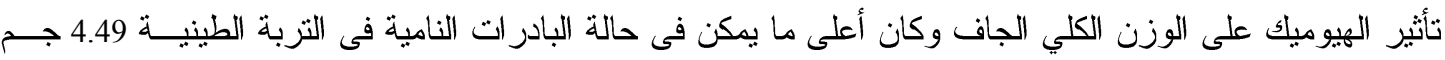

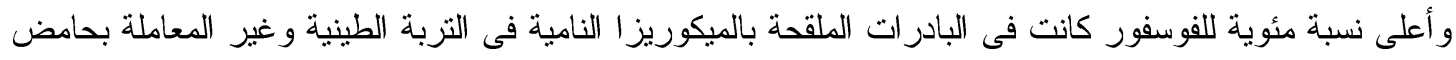

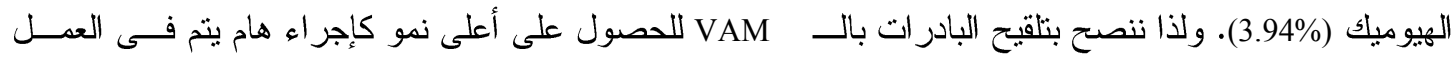
بالمشاتل وفى عمليات التشجير وبر امج مصدات الرياح وكذلك فى الأر اضى الفقيرة.
} 